\title{
A Comparative Study of English TENSE and French TENSE
}

\author{
Yimin Liu \\ English Department, Foreign Language College, Inner Mongolia University, W. Hohhot, 010021, China
}

\begin{abstract}
Since English and French, under Indo-European family, are subject to different branches, these two languages have similarities and differences which are quite essential for Chinese students either majoring in English with French as their second foreign language or in French with English as their second foreign language. The similarities between English and French make it easier for students to learn French or English, while the differences usually confuse the students' French-learning or English-learning. And above all, when students learn French TENSE, they often compare it with English TENSE, trying finding the similarities and differences between these two languages. The present paper aims at conducting a comparative study of English and French TENSES to find out the similarities and differences in their usages and structures, which is significant to enhance the students' impression of two languages' TENSES and clarify some misunderstandings in both English TENSE and French TENSE learning.
\end{abstract}

Index Terms-English, French, TENSE, comparative study

\section{INTRODUCTION}

Both English and French belong to Indo-European family, but English is one of Germanic groups and French Romance. Despite the fact that the history of Normandy Conquest is more than nine centuries long, the effect of French on English is beyond measure. After Normandy Conquest, abundant French words were flooded into English, exerting a great influence on the development of English. Since the two languages are similar in such aspects as pronunciation, lexicology and grammar, the study of the relationship between them has always been a hot spot to discuss in the study of foreign languages.

In China, lots of English majors choose French as their second foreign language and vice versa. Whether in English-learning or French-learning, for one thing, students often mix up English and French TENSES because of the similar structures, for another, they hardly succeed in clarifying the TENSE ${ }^{1}-$ the combination of tense and aspect. On this occasion, it is necessary to elaborate quite clearly the English TENSE and French TENSE respectively and conduct a comparative study of these two TENSES to find out the similarities and differences in their usages and structures.

Based on the modern grammatical system's classification of TENSE, the present paper tries to compare English TENSE and French TENSE by adopting language contrastive analysis, generating significance on the language studies and foreign language teaching. Section 2 discusses the classification of English TENSE. Section 3 shows the classification of French TENSE. Section 4 compares the two languages in TENSE.

\section{ENGLISH TENSE}

English, a marginal language between synthetic and analytic ones, has a tendency to be analytic, for English usually features the grammar through the word order and the functional words. TENSE is an essential part of grammar.

TENSE, the dominant topic in this paper, is the combination of tense and aspect. In the modern grammar system, "a tense system is a system associated with the verb where the basic contrasts in meaning have to do with the location in time of the situation, or the part of it under consideration" (Huddleston \& Pullum, 2005, p.44). But the modern grammar system indeed differentiate "time" and tense, "time" being a concept but tense a name illustrating different temporal concepts in different contexts, yet the relationship between "time" and tense in English is not at all straightforward. All of this is quite opposite to the explanation of traditional grammar system, that tense should be identified on the basis of reference to time distinction, in which case tense is basically equivalent to "time". From modern system's view, "a grammatical form or construction qualifies as an aspect if its main use is to indicate how the speaker views the situation described in the clause with respect not to its location in time but to its temporal structure or properties" (Huddleston \& Pullum, 2005, p.51).

Tense and aspect are independent grammatical categories, the former being inflectional and the latter analytic. "Modern grammatical system divides tense into present and preterit based on the inflections added to the end of verbs, and the aspect into perfective and progressive on the state where an action is" (Wu,1993, p.78). Therefore, eight kinds of TENSES are born through combining the two tenses and the two aspects.

\footnotetext{
${ }^{1}$ TENSE refers to the combination of tense and aspect in this paper, while "tense" means the location of time.
} 


\section{A. The Present Tense}

1. The present tense is basically used to indicate present time that coincides with the time of utterance, for example, Mike goes to school early everyday.

My new job is in many ways similar to that which I was doing previously.

2. The present tense is also used for situations located in future time.

a. Futurate

The futurate is the construction in which present tense is used in main clauses to specify future time by a time adjunct, for example,

Exams start next week.

The next plane is at 10 o'clock.

b. Subordinate clauses

I'll get in contact with you if I arrives in New York.

I hope you are feeling better soon.

\section{B. The Preterit}

The preterit is mainly used to locate the situation, or the part of it in past time, usually accompanied by the indicator of time. Actually, "It is not necesary, however, for the past tense to be accompanied by an overt indicator of time" (Quirk, 1985, p.184).

The People's Republic of China was founded in 1949.

He was born in 1903, died in 1969.

\section{The Present Progressive}

1. The present progressive, marked by auxiliary be followed by a gerund-participle, is used for the situation being in progress at the time of present utterance or present periods, for example,

I am reading the Chemical magazine.

She is working for the TV station now.

2. Non-durative verbs in the present progressive can indicate future reference, such as go, come, leave, arrive, land, die, start, return, join, etc.

He is leaving tomorrow.

\section{The Preterit Progressive}

The central meaning of the preterit progressive is to present the situation being in progress in past time, for example, She was waiting for us this time yesterday.

I was reading when someone knocked on the door.

Mr. White said that he was leaving for London next Monday.

\section{E. The Present Perfective}

The present perfective is marked by the auxiliary have or has, highlighting the situation located in the past. To some extent, the present perfective is similar to the simple preterit, but the difference lies in that the current relevance. "With the present perfect the past time situation is conceived of as having some kind of current relevance, relevance to the present, whereas the preterit does not express any such relationship" (Huddleston \& Pullum, 2005, p.49). For example, I have closed the door.

The example mentioned above indicates that the door is closed now.

We have done what we should do.

\section{F. The Preterit Perfect}

The preterit Prefect is composed of the auxiliary had, illustrating the situation located in the past relative to some other past time, for example,

He had already left when we arrived.

Mr. Brown had told me his plan before he left for America.

\section{G. The Present Perfect Progressive}

Marked by the auxiliary have or has and been followed by a gerund-participle, the present perfect progressive views a continuous situation located in the past, presented as being in progress and predicated to continue in the future, for example,

She has been teaching English for ten years.

Ever since their marriage, the couple have been getting along well with each other.

\section{H. The Preterit Perfect Progressive}

Marked by the auxiliary had and been followed by a past-participle, the preterit perfect progressive indicates a continuous situation located in the past relative to some other past time.

He had been waiting for you before I called him up. 
The future tense is exclusive in modern grammar system, which however, does not mean that English can not indicate the situation relating to future alternatively. With the help of auxiliary verbs, English can be used for future situation freely. This paper would like to take $d o$ as an example, "will/shall do; be going to do; be doing; be about to do; be to do". Moreover, as mentioned above, the simple present tense can also refer to the meaning regarding future tense.

\section{FRENCH TENSE}

French TENSE, like English one, is composed of tense and aspect. Tense is basically the reference to time distinction, regrading the situation located in the present, the past or the future. While aspect elaborates how the situation starts, ends or continues. Generally speaking, each French TENSE is out of three constituents-le mode, le temps et l'aspect. However, this paper focuses on the tense (le temps) and the aspect (l'aspect) of two languages. Le temps can be divided into le présent, le passé et le futur based on the situation's location in time and l'aspect into aspect duratif, aspect ponctuel, aspect inaccompli, aspect accompli, aspect itératif, aspect progressif, aspect inchoatif, aspect terminatif, aspect antérieur immédiat and aspect ultérieur imminent.

\section{A. Le Présent de L'indicatif}

1. From aspect's view, le présent de l'indicatif is inaccompli, which indicates the situation located in the time of utterance, for example,

-Que font les enfants?

- Ils jouent au football dans la cour.

Il est malade, mais il ne veut pas aller voir le docteur.

2. It indicates a situation occurring in the past but continuing till the time of utterance, for example,

Elle travaille depuis l'âge de 16 ans.

Il ne fume plus depuis plusieurs mois déjà.

(cited from Zhou, 2011, p.114)

3. It indicates a situation located repetitively or habitually, for example,

Le Samedi, nous allons à la pisicine.

Elle chante toujours sous la douche.

4. It signifies a well-known truth or fact, for example,

Le Soleil est une étoile.

L'union fait la force.

5. It can be used for a situation located in the future, for example,

Attendez-moi, je reviens tout de suite.

Je pars en vacances demain.

\section{B. Le Passé Composé}

Le passé composé is a complex tense, marked by le présent de l'indicatif de l'auxiliaire être or avoir and the past participle. It belongs to l'aspect accompli.

It is for an accomplished action relative to the time of utterance, for example,

C'est bon! J'ai enfin terminé mes devoirs.

Je t'ai acheté des cerises; je sais que tu adores ça.

(b) It indicates a situation located within certain time, for example,

Je t'ai attendu pendant cinq minutes.

Ce matin, je me suis levé trop tard.

(c) It emphasizes a present state (état présent) influenced by a situation located in the past, for example, Nicolas est parti il y a trois heures.

-Est-ce que tu as fini tes devoirs?

-Oui, je les ai déjà finis.

\section{L'imparfait}

1. It can be used for a continuous and unaccomplished action or state in the past time, without the clear starting or ending line, for example,

Elle était ouvrière avant d'entrer à l'université.

Sa femme habitait dans une vieille maison quand il était tout petit.

(cited from Zhou, 2011, p.128)

2. With continuation, it is for a situation in progress in the past time, for example,

Monsieur Richer n'a pas pu participer à cette réunion, parce qu'il était en voyage à l'étranger.

Le professeur est entré dans la classe, pendant que nous chantions et dansions.

3. It also indicates a situation located habitually in the past time, with the occurrence of such adverbs as toujours, souvent, chaque matin, toutes les semaines.

Quand j'étais petite; je me levais chaque jour à sept heures. 
Autrefois, Eva faisait souvent de la natation.

Here, it is necessary to clear the differences between l'imparfait and le passé composé. The former indicates the past and continuous action whose starting and ending time are not known, while the latter offers the relevant occurring time. Besides, l'imparfait emphasizes the continuous situation repetitively or habitually located, but le passé composé focuses on the repetitive situation which are not continuous any more.

\section{Le Passé Simple}

1. Le passé simple is used for a situation located in the relatively far past time and separated with the current state, for example,

Il finit par rentrer.

Il se leva, prit son manteau, ouvrit la porte et disparut dans la nuit.

2. Le passé simple is mainly applied to describe historical events, stories, fictions and biographies, for example,

Victor Hugo mourut en 1885 .

Einstein naquit en 1879.

L'homme fut l'euvre du sixième jour de Dieu.

\section{E. Le Passé Immédiat}

Le passé immédiat, composed of le présent de l'indicatif de venir de followed by the verb, for example,

Il vient de quitter Paris.

Je viens de boire une tasse de café.

\section{F. Le Plus-que-parfait de L'indicatif}

Marked by l'imparfait de être or avoir and the past participle, le plus-que-parfait de I'indicatif is usually used with le passé composé, l'imparfait or le passé simple, indicating the situation located in the past relative to another past time, for example,

Ma mère s'était coucheé quand je suis rentré chez moi.

Il crut que je n'avais pas bien compris ses intentions.

Depuis que sa mère avait quitté, elle restait à la maison.

\section{G. Le Passé Antérieur}

The grammatical meaning of le passé antérieur is the same as le plus-que-parfait de I'indicatif, except for one thing that le passé antérieur is only collocated with le passé simple, for example,

Quand ses parents furent partis, il alluma l'ordinateur.

Dès qu'elle eut fini ses devoirs, elle aida à faire le ménage.

Aussitôt qu'il fut parti, le directeur lui téléphona.

\section{H. Le Futur Simple}

Le futur simple indicates the situation located in the near or distant future.

1. It signifies a thing that will occur at a certain time in the future.

D'après les prévisions, l'avion atterrira ce soir à 21 heures.

Jean Pierre aura 60 ans en l'an 2013.

2. a continuous action in the future

L'année prochaine, nous passerons quelques semaines à l'anglais.

3. a situation located respectively in the near or distant future

Tous les matins, vous ferez une heure de gymnastique, puis vous irez courir vingt minutes.

\section{Le Futur Antérieur}

In the aspect, le futur anterieur belongs to l'aspect accompli; in the tense, it indicates the situation located in the future relative to another future time, accompanied by such temporal adverbs as quand, lorsque, dès que, aussitôt que, après que, for example,

Je te téléphonerai dès que je serai arrivé.

Quand tu auras fini tes travailles, tu pourras sortir.

\section{J. Le Futur Immédiat}

Le futur immédiat, orally used, indicates the situation located in the future time closely associated with the present time, marked by le présent de l'indicatif d'aller followed by infinitif, for example,

Je vais rentrer chez moi.

On va passer des examens.

\section{K. Le Futur dans Le Passé}

Le futur dans le passé can indicate the situation located in the future relative to some past time, for example,

Le directeur leur avait dit qu'ils ne pourraient revenir à l'usine qu'avec des cheveux courts. 
Je pense que je n'aurais aucune difficulté pour passer cet examen.

(cited from Ma, 2010, p.412)

\section{The COMPARISON BETWEEN ENGLISH TENSE AND FRENCH TENSE}

\section{A. Le Présent de L'indicatif}

1. Le Présent de L'indicatif_-The Present Tense

a. Le Présent de L'indicatif in French and the present tense in English both can signify the undoubtful fact or truth, for example,

La lune tourne autour de la Terre.

The moon moves around the earth.

月亮围着地球转。

b. the situation frequently or habitually located;

Tous les matins, je fais une promende.

I take a walk every morning.

我每天早晨都会散步。

c. the current state or features possessed by a person or a thing;

Cette machine marche très bien.

This machine runs very well.

这台机器运行得很好。

2. Le Présent de L'indicatif—The Present Progressive

To some extent, le présent de l'indicatif in French is equal to the present progressive, signifying the situation being in progress at the time of present utterance or present periods, for example,

- Qu'est ce que tu fais?

- Je fais mes devoirs.

-What are you doing?

-I'm doing my homework.

一你正在干什么呢?

一我正在做作业。

3. Le Présent de L'indicatif-The Present Perfective

The great difference between French TENSE and English TENSE lies in that the former does not have perfective, instead, le présent de l'indicatif is used for the meaning expressed by the present perfective in English, for example,

Elle apprend l'anglais depuis 4 ans.

She has studied English for four years.

她已经学习了四年英语。

4. Le Présent de L'indicatif-Futurate

Like present tense in English, le présent de l'indicatif in French can be used for situations located in future time, for example,

Je pars demain.

I start tomorrow.

我明天就动身。

\section{B. L'imparfait}

1. L'imparfait-The Preterit Progressive

a. the situation being in progress at the time of past periods;

Quand je suis entré, Pierre regardait la télévision.

When I came in, Pierre was watching TV.

当我进来的时候, 皮埃尔正在看电视。

Il regardait la télé pendant que nous faisions nos devoirs.

While he was watching TV, I was doing my homework.

当他在看电视的时候, 我正在做作业。

b. the characters of objects or surroundings;

Il pleuvait hier.

It was raining yesterday.

昨天下了雨。

La neige couvrait la terre.

The snow was covering over the ground.

雪覆盖着大地。

2. L'imparfait-The Preterit 
Il travaillait toujours jusqu'a minu. He always worked till the mid-night. 过去, 他总是工作到深夜。

Avant, il habitait à la campagne. He lived in the village in the past. 他过去住在乡村。

\section{Le Passé Simple}

Le Passé Simple-The Preterit

La République Populaire de Chine fut proclaméé le 1er Octobre 1949.

The People's Republic of China was founded on October 1st, 1949.

中华人民共和国成立于 1949 年 10 月 1 日。

In French, le passé simple, less frequently used than l'imparfait, finds its place in writings.

\section{Le Passé Composé}

1. Le Passé Composé-The Present Perfective

J'ai porté mon parapluie.

I have carried my umbrella.

我已经带上雨伞了。

2. Le Passé Composé-The Preterit

Il est né en 1902.

He was born in 1902 .

他生于 1902 年。

\section{E. Le Passé Immédiat}

Le Passé Immédiat—The Present Perfective/The Preterit

Je viens de finir mon travail.

I have just finished my work./I finished my work just now.

我已经完成我的作业了。/我刚刚完成我的作业。

Marie vient d'écrire une lettre à ses parents.

Mary has written a letter to her parents./ Mary wrote a letter to her parents.

玛丽给她父母写了一封信。

\section{F. Le Plus-que-parfait de I'indicatif}

Le Plus-que-parfait de I'indicatif-The Preterit Perfective

To some extent, it is similar to the preterit perfective not only in the meaning expressed but in the structure, for example,

Pierre avait déjà parti pour Allemand quand nous avons arrivés ici.

Pierre had already left for German when we arrived here.

当我们到达这里的时候, 皮埃尔已经去德国了。

\section{G. Le Passé Antérieur}

Le Passé Antérieur-The Preterit Perfective

Both of them indicate the situation located prior to a past time, for example,

Dès qu'il eut fini son travail, il aida les autres.

He helped others as soon as he had finished his work.

他一干完自己的活儿就去帮助别人了。

\section{H. Le Futur dans Le Passé}

Le Futur dans Le Passé-The Preterit Future

Both le futur dans le passé and the preterit future can indicate the situation located in the future relative to some past time, for example,

Les étudiants ont dit qu'ils visiteraient Notre Dame de Paris le lendemain.

The students said that they would visit Notre Dame de Paris the nest day.

同学们说他们第二天要去游览巴黎圣母院。

Ils se rendaient compte que leur voyage serait difficile et dangereux.

They realized that their journey would be hard and dangerous.

他们意识到了他们的这场旅行将困难重重, 充满危险。

\section{Le Futur Simple}

Le Futur Simple-The Future 
Le train arrivera deux heures.

The train will be arriving at two o'clock.

火车两点到站。

Je suis sûr(e) que je ne me suis pas perdus dans la forêt.

I'm sure that I shall not lose my way in the woods.

我相信我不会再树林中迷路的。

In French, le futur simple, with the second person pronoun as subject, can be used for willing, order or advice, which is similar to the English structure of "will/shall do" whose subject is beyond second person pronoun, for example,

Vous prendrez la deuxième route à gauche.

You shall/will follow the second road on your left.

您走左边第二条路吧。

\section{J. Le Futur Immédiat}

Le Futur Immédiat-The Future

Je vais le faire dans un instant.

I'm going to do it in a moment./I'm about to do it in a moment.

我一会儿就做。

On va passer des examens.

We will succeed in the examinations.

我们会通过考试的。

\section{K. Le Futur Antérieur}

Le Futur Antérieur-The Present Perfective/The Future Perfective

J'irai au cinéma aussitôt que j'aurai fini mes devoirs.

As soon as I have finished my homework, I'll go to cinema.

我一做完作业就去看电影了。

Quand le soleil se couchera demain, les voyageurs seront revenus à l'hôtel.

When the sun goes down tomorrow, the tourists will have been back in the hotel.

明天太阳落山时, 旅客们已经回到旅馆了。

TABLE

NOW, A CHART IS PRESENTED TO CLARIFY THE COMPARISON BETWEEN ENGLISH TENSE AND FRENCH TENSE

\begin{tabular}{|l|l|l|l|}
\hline \multicolumn{1}{|c|}{ French } & \multicolumn{1}{c|}{ English } & \multicolumn{1}{c|}{ French } & \multicolumn{1}{c|}{ English } \\
\hline Le Présent de L'indicatif & $\begin{array}{l}\text { The Present Tense } \\
\text { The Present Progressive } \\
\text { The Present Perfective } \\
\text { Futurate }\end{array}$ & L'imparfait & \\
\hline Le Passé Simple & The Preterit & Le Passé Composé & $\begin{array}{l}\text { The Present Perfective } \\
\text { The Preterit }\end{array}$ \\
\hline Le Passé Immédiat & $\begin{array}{l}\text { The Present Perfective } \\
\text { The Preterit }\end{array}$ & $\begin{array}{l}\text { Le Plus-que-parfait de } \\
\text { I'indicatif }\end{array}$ & The Preterit Perfective \\
\hline Le Passé Antérieur & The Preterit Perfective & Le Futur dans Le Passé & The Preterit Future \\
\hline Le Futur Simple & The Future & Le Futur Immédiat & The Future \\
\hline Le Futur Antérieur & $\begin{array}{l}\text { The Present Perfective } \\
\text { The Future Perfective }\end{array}$ & & \\
\hline
\end{tabular}

\section{CONClusion}

TENSE, being the essential part of grammar-learning, serves the students as a foundation for learning a language. Contrastive analysis is always considered as an effective approach to learning a language. Therefore, the contrastive analysis of English and French TENSES has great significance in foreign language learning and teaching field.

A successful comparison between English and French TENSES is of great importance for not only English majors with French as their second foreign language but also the French majors with English as their second foreign language or those who are interested in these two languages. All of them should clearly recognize the similarities and differences between English and French TENSES to facilitate their study in the two languages.

In conclusion, TENSE is an important part in grammar-learning. Only when we have a deep understanding of English and French TENSES can we better understand the two languages we are learning.

\section{REFERENCES}

[1] Huddleston, R \& Pullum, G.K. (2005). A Student's Introduction to English Grammar. New York: Cambridge University Press.

[2] Ma Xiaohong \& Lin Xiaoyu. (2010). Le Français. Beijing: Foreign Language Teaching and Research Press.

[3] Quick, R. (1985). A Comprehensive Grammar of the English Language. London: Longman. 
[4] Wu Shixiong. (1993). A Study of English and French TENSE. Journal of Fu Zhou Normal University, 46, 76-80.

[5] Zhou Li. (2011). Grammaire Descriptive de La Langue Française. Shanghai: Dong Hua University Press.

Yimin Liu, whose profession is applied linguistics, is a postgraduate in Inner Mongolia University. The email address is lymhannah@163.com.

Yimin Liu was born in Inner Mongolia, China in 1990. She received her Bachelor degree in English Language and Literature from Chang An University, China in 2013.

She is currently a postgraduate student in the School of Foreign Languages, Inner Mongolia University, Inner Mongolia, China. Her research interests include general linguistics and French literature. 